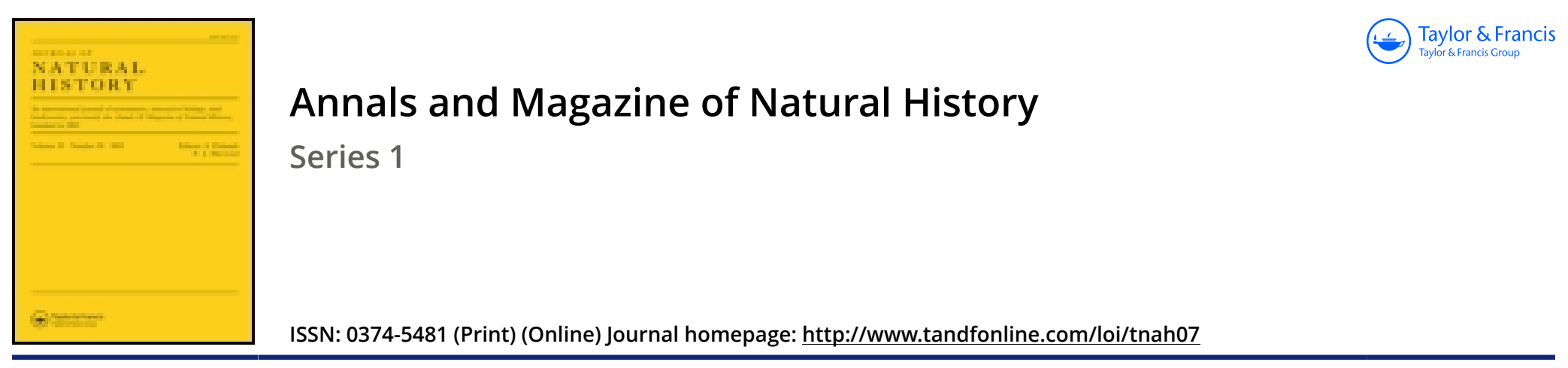

\title{
Chamæa, a new genus of birds allied to Parus
}

\section{Wm. Gambel}

To cite this article: Wm. Gambel (1847) Chamæa, a new genus of birds allied to Parus, Annals and Magazine of Natural History, 20:136, 441-442, DOI: 10.1080/037454809496086

To link to this article: http://dx.doi.org/10.1080/037454809496086

册Published online: 23 Dec 2009.

Submit your article to this journal 준

LII Article views: 1

Q View related articles $\asymp$ 
quently merely indicated by empty places where the absent organs are never developed, as is very readily seen with respect to the stamina of those plants. We may therefore infer among the ordinary causes of disturbance in the floral symmetry, such as abortion, multiplication, degenerescence and adhesion, likewise that of the nondevelopment of organs.

2. With respect to the origin of the union of the stamina called monadelphous, diadelphous, polyadelphous and synantherous, their adhesion is always subsequent to their first formation. The family of the Stylidia (Stylidium adnatum) alone appears to me to furnish a remarkable exception to this rule as regards the adhesion of the styles.

I shall here enumerate three principal kinds of irregularity among all the irregular corollas which I have examined :-

1. Irregularity by simple inequality of development among the several segments of the corolla, with complication of adhesion or complete atrophy or arrest of growth; this is the most common.

2. Irregularity by deviation, where the segments although equal turn all of the same side ; for instance, the corolla of Sccevola lavigata (Goodeniacea), and the genera with ligulate florets of the Composita.

3. Irregularity by simple metamorphosis of the stamina, as in the family of the Cannea, and probably that of the Zingiberacea.-Comptes Rendus, Aug. 16, 1847.

Chamza, a new genus of Birds allied to Parus. By W.r. Gamber.

Bill short, tapering to the point, acute and compressed. Both mandibles entire, ridge of upper elevated, and curving nearly from the base; the depression for the nostrils large, oval and exposed; the nostrils opening beneath a membrane in the depression. Wings very short and much rounded. Tail very long and graduated. Tarsus long.

Chamea fasciata, nobis. Ground Tit.

Parus fasciatus, nobis, Proceed. Acad. Nat. Sci. vol. ii. p. 265.

This interesting bird, placed provisionally among the Titmice, I have now made the type of a new genus, not being able as yet to find a suitable place for it among those already described.

For several months before discovering the bird, I chased among the fields of dead mustard stalks, the weedy margins of streams, low thickets and bushy places, a continued, loud, crepitant, grating scold, which I took for that of some species of wren, but at last found to proceed from this wren-tit, if it might so be called. It is always difficult to be seen, and keeps in such places as $I$ have described, close to the ground; eluding pursuit by diving into the thickest bunches of weeds and tall grass, or tangling bushes, uttering its grating wrenlike note whenever an approach is made towards it.

But if quietly watched, it may be seen, when searching for insects, to mount the twigs and dried stalks of grass sideways, jerking its long tail, and keeping it erect like a wren, which, with its short wings, in such a position it so much resembles; at the same time uttering Ann. \&Mag. N. Hist. Vol.xx. Suppl. 
a very slow, monotonous, singing, chickadee note, like pee pee pee pee peep; at other times its notes are varied, and a slow, whistling, continued pwit, pwit, pwit, pwit, pwit, pwit, may be heard. Again, in pleasant weather towards spring, I have heard them answering one another, sitting upon a low twig, and singing in a less solemn strain, not unlike a sparrow, a lively pit, pit, pit, tr $r r r r r r$, but if disturbed, at once resuming their grating scold.-Silliman's Journal for Sept. 1847.

\section{METEOROLOGICAL OBSERVATIONS FOR OCT. 1847.}

Chiswick.-October 1. Hazy : cloudy. 2. Cloudy. 3. Light clouds and fine : overcast. 4. Foggy : fine. 5. Fine : light clouds : clear at night. 6. Dense fog: very fine : lightning and rain at night. 7 . Fine : rain : lightning at night : clear. 8. Very fine. 9, 10. Rain. 11. Rain in forenoon: clear at night. 12. Slight fog: very fine. 13. Foggy: hazy : cloudy at night. 14. Hazy and drizzly: cloudy. 15. Hazy and cold : slight rain. 16. Foggy : very fine. 17. Foggy, with slight drizzle : very fine. 18. Slight fog: rain. 19. Exceedingly fine : rain. 20. Very fine : rain at night. 21. Rain : clear at night. 22. Fine. 23. Densely clouded and boisterous : rain. 24. Slight showers, 25. Very clear : fine: clear and frosty. 26. Frosty: uniformly overcast. 27. Fine : rain. 28. Hazy and mild. 29. Exceedingly fine. 30. Overcast and mild. 31. Cloudy and mild.
Mean temperature of the month $52^{\circ} \cdot 14$
Mean temperature of Oct. 1846
Mean temperature of Oct. for the last twenty years ...... $50 \cdot 42$
Average amount of rain in Oct.

$2 \cdot 60$ inches,

Boston.-Oct. I-5. Cloudy. 6. Rain. 7. Fine: rain P.M. 8. Fine. 9. Fog: eclipse of the sun invisible until three-quarters over : fog. 10. Rain : rain A.M. 11-13. Fine. 14, 15. Cloudy. 16. Fine. 17, 18. Fog. 19, 20. Fine. 21. Cloudy : rain A.M. 22. Fine. 23. Cloudy : rain P.M. 24-26. Fine. 27. Rain : rain A.M. and P.M. 28. Fog. 29. Rain: rain A.M. 30. Fine : rain A.M. 31. Cloudy.

Sandwick Manse, Orkney.-Oct. 1. Clear: cloudy. 2. Cloudy : clear. 3. Cloudy. 4. Cloudy : drops. 5. Bright : showers. 6. Showers. 7. Drizzle. 8. Drizzle : clear : aurora. 9. Clear : cloudy. 10. Cloudy : drizzle, 11. Clear : fog. 12. Fog. 13. Cloudy : clear: aurora. 14, Cloudy : clear. 15,16. Clear: cloudy. 17. Showers : drizzle. 18. Rain. 19. Damp : rain. 20, 21. Showers: clear. 22. Showers : rain. 23. Showers : sleet-showers. 24. Sleet-showers. 25. Clear. 26. Drops : showers. 27. Bright: drops. 28. Cloudy. 29. Cloudy : shower : lightning. 30. Showers : rain. 31. Bright : cloudy.

Applegarth Manse, Dumfries-shire-Dot. 1, 2. Chill and droughty. 3, 4. Dull, but fair. 5. Fair A.M. : showery P.M. 6. Heavy rain A.M. 7. Heavy rain A.M. : flood. 8. Frequent showers. 9. Fine A.M.: rain P.M, 10. Heavy rain. 11. Fair: rain in the night preceding. 12. Fair and fine. 13. Fair, but raw and cloudy. 14,15. Fair, though chilly. 16. Very fine clear day. 17. Dull and cloudy. 18. Dull and cloudy : rain P.M. 19. Heavy rain. 20, 21. Occasional showers. 22. Rain A.M.: very heavy P.M. 23. Rain early A.M.: fine day. 24. Heavy showers. 25. Fair: fine : clear. 26. Rain nearly all day. 27. Heavy rain and flood. 28. Fog : cleared P. 3. 29. Fair and fine. 30. Fair A.M. : heavy rain P.M. 31. Rain early A.M. : cleared.
Mean temperature of the month
Mean temperature of Oct. 1846
$49^{\circ} \cdot 5$
Mean temperature of Oct. for twenty-five years .............. $49 \cdot 6$
A verage rain in Oct. for twenty years ..................... 3.56 inches.
Rain in Oct. 1847 